\title{
Intriguing diversity among diazotrophic picoplankton along a Mediterranean transect: a dominance of rhizobia
}

\author{
M. Le Moal ${ }^{1}$, H. Collin ${ }^{1,2}$, and I. C. Biegala ${ }^{1}$ \\ ${ }^{1}$ CNRS-INSU/IRD/Université de la Méditerranée, UMR 6535, Laboratoire d'Océanographie Physique et Biogéochimique, \\ Centre d'Océanologie de Marseille, 11 rue Batterie des Lions, 13007 Marseille, France \\ ${ }^{2}$ Département d'Ecologie et d'Evolution, Université de Lausanne, Sorge, Le Biophore, 1015 Lausanne, Switzerland
}

Received: 22 November 2010 - Published in Biogeosciences Discuss.: 2 December 2010

Revised: 21 March 2011 - Accepted: 22 March 2011 - Published: 29 March 2011

\begin{abstract}
The Mediterranean Sea is one of the most oligotrophic marine areas on earth where nitrogen fixation has formally believed to play an important role in carbon and nitrogen fluxes. Although this view is under debate, the diazotrophs responsible for this activity have still not been investigated in the open sea. In this study, we characterised the surface distribution and species richness of unicellular and filamentous diazotrophs across the Mediterranean Sea by combining microscopic counts with size fractionated in situ hybridization (TSA-FISH), and 16S rDNA and nifH genes phylogenies. These genetic analyses were possible owing to the development of a new PCR protocol adapted to scarce microorganisms that can detect as few as 1 cell ml ${ }^{-1}$ in cultures. Low concentrations of diazotrophic cyanobacteria were detected and this community was dominated at $99.9 \%$ by picoplankton hybridized to the Nitro821 probe, specific for unicellular diazotrophic cyanobacteria (UCYN). Among filamentous cyanobacteria only 0.02 filament $\mathrm{ml}^{-1}$ of Richelia were detected in the eastern basin, while small $(0.7-1.5 \mu \mathrm{m})$ and large $(2.5-3.2 \mu \mathrm{m})$ Nitro821-targeted cells were recovered at all stations with a mean concentration of $3.5 \mathrm{cell} \mathrm{ml}^{-1}$. The affiliation of the small Nitro821-targeted cells to UCYN-A was confirmed by $16 \mathrm{~S}$ and nifH phylogenies in the western Mediterranean Sea. In the central and the eastern Mediterranean Sea no 16S rDNA and nifH sequence from UCYN was obtained as cells concentration were close to, or below PCR detection limit. Bradyrhizobium sequences dominated nifH clone libraries from picoplanktonic size fractions. A few sequences of $\gamma$-proteobacteria were also detected in the central Mediterranean Sea. While low phosphate and iron concentrations could explain the absence of Trichodesmium sp., the factors that prevent the develop-
\end{abstract}

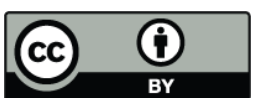

Correspondence to: I. C. Biegala (biegala@univmed.fr) ment of UCYN-B and C remain unknown. We also propose that the dominating picoplankters probably developed specific strategies, such as associations with protists or particles, and/or photosynthetic activity, to acquire carbon for sustaining diazotrophy.

\section{Introduction}

The Mediterranean Sea has long been recognized for the strong oligotrophy of its waters, with a clear decrease in nutrient concentration and primary productivity from west to east (Moutin and Raimbault, 2002). Deep Mediterranean waters are characterized by unusually high $\mathrm{N}: \mathrm{P}$ ratios compared to Redfield (Béthoux and Copin-Montégut, 1986; Krom et al., 1991). The processes that induce such atypical ratios are under debate, and two hypotheses have been proposed, involving either significant diazotrophic activity, or low denitrification rates in combination with external inputs of nutrients (Béthoux and Copin-Montégut, 1986; Krom et al., 2010). Direct $\mathrm{N}_{2}$ fixation measurements conducted in the eastern and western Mediterranean basins have shown mainly low diazotrophic activity with punctual peaks at different sites or seasons $\left(0.01-129 \mathrm{nmol} \mathrm{N} \mathrm{L}^{-1} \mathrm{~d}^{-1}\right.$, Rees et al., 2006; Sandroni et al., 2007; Ibello et al., 2010). This heterogeneity in rates of $\mathrm{N}_{2}$-fixation implies the need of high frequency surveys to fully integrate, over the long term, the role of diazotrophy in Mediterranean biogeochemical cycles. However, the importance of diazotrophy has been argued to be inconsistent with the known phosphate-starved conditions found in the Mediterranean Sea (Krom et al., 2004, 2010), as diazotrophic activity was demonstrated to be controlled by phosphate in areas dominated by Trichodesmium sp. (Saňudo-Wilhelmy et al., 2001; Moutin et al., 2005). Trichodesmium sp., a filamentous cyanobacterium, has been

Published by Copernicus Publications on behalf of the European Geosciences Union. 
regarded for a long time as the main marine $\mathrm{N}_{2}$ fixer (Falkowski, 1997). This view has now changed because $\mathrm{N}_{2}$-fixation measurements within small $(<10 \mu \mathrm{m})$ and large $(>10 \mu \mathrm{m})$ planktonic size fractions suggest that unicellular diazotrophs fix equally or more nitrogen than filamentous species (Montoya et al., 2004; Biegala and Raimbault, 2008). Due to their higher surface/volume ratios, small cells have been recognised to be better adapted to phosphate-limiting conditions than larger ones (Smith and Kalff, 1982; Falcón et al., 2005). This is coherent with past and recent Mediterranean observations (Trégouboff, 1957; Bar Zeev et al., 2008) which reported only low concentrations of filamentous cyanobacteria, while smaller diazotrophs were hypothesized to be the main planktonic $\mathrm{N}_{2}$-fixers in this environment (Béthoux and Copin-Montégut, 1986). Acquiring information on the size, the diversity and the spatio-temporal distribution of diazotrophs is thus essential to improve our understanding of Mediterranean biogeochemical cycles.

To date significant diversity has been recovered among marine planktonic diazotrophs. While filamentous organisms include essentially Trichodesmium sp. and the diatom symbiont Richelia intracellularis, unicellular diazotrophs are highly diverse and embrace Cyanobacteria, Proteobacteria, and Archaea. So far, three groups of unicellular diazotrophic cyanobacteria (UCYN) have been reported in the literature, UCYN-A, B, and C (Zehr et al., 2001; Foster et al., 2007). While UCYN-B and C are nanoplanktonic cells (2 to $10 \mu \mathrm{m}$ ) closely affiliated to the cultivated strains Crocosphaera watsonii and Cyanothece sp., respectively (Church et al., 2005a; Foster et al., 2007), UCYN-A are of picoplanktonic size $(0.7-1.5 \mu \mathrm{m}$, Biegala and Raimbault, 2008; Goebel et al., 2008) and so far uncultivated. In addition to being freeliving, UCYN have also been suggested to produce mucilage, to attach to inert particles or to live in association with planktonic eukaryotes (Biegala and Raimbault, 2008; Bonnet et al., 2009). These observations imply that UCYN could also contribute to nitrogen fixation of the large size fraction, thus reinforcing their role in global diazotrophic activity.

In the Mediterranean Sea, only two coastal studies have revealed the presence of unicellular diazotrophs (ManAharonovich et al., 2007; Le Moal and Biegala, 2009). Organisms affiliated to UCYN-A, Proteobacteria, and Archaea were recovered in the south-eastern basin and were expressing their nifH gene, which encodes the dinitrogenase reductase enzyme involved in nitrogen fixation process (Man-Aharonovich et al., 2007). In the north-western Mediterranean Sea, putative pico and nanoplanktonic UCYN were detected and hypothesized to belong to UCYN-A and UCYN-B or C, respectively (Le Moal and Biegala, 2009). Their concentrations were low along a seasonal cycle (4.6 cell ml ${ }^{-1}$ ) compared to abundance estimates from other oceanic basins (reviewed in Le Moal and Biegala, 2009; Moisander et al., 2010), except for summer abundances that reached $1900-5300 \mathrm{cell} \mathrm{ml}^{-1}$. While UCYN and filamentous diazotrophic cyanobacteria have been investigated in coastal waters, their spatial distributions have never been characterized in the open Mediterranean Sea.

Different molecular approaches have been used in the literature to study (i) the concentrations and (ii) the species richness of diazotrophs. First, concentrations have been determined either with the help of the quantitative polymerase chain reaction (qPCR) of nifH copies or by direct microscopic counts of fluorescently labeled UCYN, using a specific 16S rDNA probe combined with tyramide signal amplification-fluorescence in situ hybridization (TSA-FISH, Church et al., 2005a; Biegala and Raimbault, 2008). It was possible to design a specific $16 \mathrm{~S}$ oligonucleotide for UCYN (Nitro821, Mazard et al., 2004) as the co-evolution of both nifH and 16S rDNA genes has resulted in similar phylogenies, especially in the phylum Cyanobacteria (Rosado et al., 1998; Zehr et al., 2003). Compared to qPCR, the whole cell hybridization technique allows characterizing UCYN size and provides some information on their ecology such as their free living or associated life styles (Biegala and Raimbault, 2008). However, visual discrimination among UCYN-B and -C is not possible and requires complementary species richness analysis. Therefore, the species richness can be investigated in a second time using PCR and phylogenetic techniques on 16S rDNA and nifH genes. Such information is tricky to acquire for diazotrophs less concentrated than 10 cell $\mathrm{ml}^{-1}$ (Kirshtein et al., 1993; Mazard et al., 2004) as their DNA may be diluted too much during the different extraction steps. To increase the amount of target within extracted DNA, a nested approach using the nifH gene was introduced (Zani et al., 2000). However, several studies still reported the inability to detect low concentrations of diazotrophs at the DNA level (e.g. Zani et al., 2000; ManAharonovich et al., 2007), thus illustrating the need to develop an adapted PCR protocol for scarce microorganisms in this field of research.

Planktonic diazotrophic activity has long been attributed to cyanobacteria, as they can sustain this energetically expensive process via photosynthesis (Stewart, 1971). Conversely, non-cyanobacterial diazotrophs are considered unable to acquire an autonomous carbon source through photosynthesis, and have thus been neglected in biogeochemical studies (Madigan, 1995; Tyrell, 1999). However, this metabolic function has also recently been missing within UCYN-A (Zehr et al., 2008), although these picocyanobacteria can actively express nifH gene and can reach high concentrations (Church et al., 2005b; Moisander et al., 2010). Similar nifH expression patterns were measured among planktonic proteobacteria, for which phototrophy has not been discovered (Zehr et al., 2007; Riemann et al., 2010). These results underline the importance to characterize the entire diazotrophic community including Proteobacteria and Archaea to better understand their role into global nitrogen fixation.

In this study we used a combination of approaches (i) to assess the distribution of diazotrophic cyanobacteria using epifluorescence microscopy for filamentous cells and 
size-fractionated TSA-FISH technique for the UCYN; (ii) to identify the species richness of UCYN as well as those of potential other non-cyanobacterial diazotrophs, by specific $16 \mathrm{~S}$ and general nifH phylogenetic analyses; and (iii) to develop a protocol for PCR amplifying scarce organisms necessary for phylogenetic analyses.

\section{Material and methods}

\subsection{Natural environment sampling and cultures}

Two types of samples were used in this study, environmental samples to determine diazotroph distributions and species richness across the Mediterranean Sea, and a combination of cultures and environmental samples to develop a protocol for PCR amplifying scarce diazotrophs.

Mediterranean samples were collected during the oceanographic BOUM transect (Biogeochemistry of Oligotrophic to Ultra-Oligotrophic Mediterranean) in June-July 2008 onboard the R/V Atalante. For TSA-FISH assays, ten liters of water were sampled using Niskin bottles at $5 \mathrm{~m}$ depth from 13 stations across the oligotrophic gradient (Fig. 1). At stations A, B, and C (Fig. 1), two nutrient contrasted depths were sampled: an oligotrophic one at $12.5 \mathrm{~m}$ and a nutrient rich one at the upper deep chlorophyll maximum $\left(\mathrm{DCM}^{+}\right)$ at $80 \mathrm{~m}, 120 \mathrm{~m}$, and $100 \mathrm{~m}$ for each of the three stations, respectively. Cells collected at $12.5 \mathrm{~m}$ from stations A, B, and $\mathrm{C}$ were also used as DNA template for PCR reactions necessary for phylogenetic studies.

For methodological development, the strain Crocosphaera watsonii WH8501 was used to define the detection limit of 16S rDNA PCR amplification on unicellular diazotrophic cyanobacteria. The $C$. watsonii strain was graciously provided by $\mathrm{T}$. Shi and was grown under $12 / 12 \mathrm{~h}$ light/dark conditions on a modified YBCII medium (Chen et al., 1996). Two milliliters of culture were fixed with $1 \%$ paraformaldehyde (PFA) and stored at $-80^{\circ} \mathrm{C}$ until further analyses inculding serial dilutions, counts by flow cytometry and PCR amplification. Environmental samples collected in different marine areas, such as samples $M$ (Mediterranean Sea, $43^{\circ} \mathrm{N} ; 5^{\circ} \mathrm{E}$ ) and samples $\mathrm{P}$ (Pacific Ocean, $22^{\circ} \mathrm{S}, 166^{\circ} \mathrm{E}$ ) were stored for one to five years at $-80^{\circ} \mathrm{C}$ to test the stability of PCR efficiency with time. Two types of DNA samples were used, either DNA from entire cells collected on filters following the same protocol as the one for TSA-FISH experiments (see below for TSA-FISH) or extracted DNA (see below PCR and cloning).

\subsection{TSA-FISH and microscopy}

Before TSA-FISH experiments, plankton from sea water samples were collected from three size fractions $(0.2-3 \mu \mathrm{m}$, $3-10 \mu \mathrm{m}$, and $>10 \mu \mathrm{m})$. Depending on the degree of oligotrophy, 1.3-8.2 liters were filtered by gravity through $10 \mu \mathrm{m}$

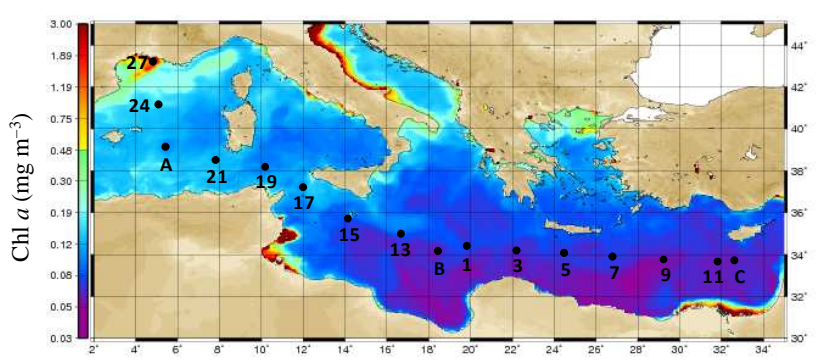

Fig. 1. Position of sampled stations during the BOUM transect across the Mediterranean Sea. Numbers (1-27) represent stations where surface TSA-FISH analyses were done and letters (A, B, and $\mathrm{C}$ ) represent stations where TSA-FISH analyses were done at $12.5 \mathrm{~m}$ and $\mathrm{DCM}^{+}$as well as $16 \mathrm{~S}$ and nifH phylogenies at $12.5 \mathrm{~m}$.

ISOPORE $^{\mathrm{TM}}$ (Millipore, France) $47 \mathrm{~mm}$ filters, and 0.83.4 liters of the remaining filtrate were collected by gravity on $3 \mu \mathrm{m}$ ISOPORE $^{\mathrm{TM}}$ (Millipore, France) $47 \mathrm{~mm}$ filters. Then, $200 \mathrm{~mL}$ of the $<3 \mu \mathrm{m}$ filtrate were collected under $200 \mathrm{mmHg}$ vacuum on $0.2 \mu \mathrm{m}$ ISOPORE ${ }^{\mathrm{TM}}$ (Millipore, France) $47 \mathrm{~mm}$ filters. Cells were subsequently fixed with buffered 1\% PFA for $15 \mathrm{~min}$ at room temperature (RT), dehydrated with $100 \%$ ethanol for $10 \mathrm{~min}$ at RT, and stored at $-80^{\circ} \mathrm{C}$ until analyses, according to Biegala and Raimbault (2008). Prior to hybridizations, filters containing fixed cells were covered with agarose to avoid cell loss during hybridization steps, according to Biegala and Raimbault (2008), with slight modification in Le Moal and Biegala (2009), where $0.4 \%$ agarose was used instead of $0.1 \%$ for the $>10 \mu \mathrm{m}$ size fraction. Hybridizations were done according to the protocol of Biegala et al. (2002), modified in Biegala and Raimbault (2008). Briefly, unicellular diazotrophic cyanobacteria were hybridized with the Horse Radish Peroxidase-labeled 16S rDNA Nitro821 probe (Thermo, Germany, 5'-CAA GCC ACA CCT AGT TTC-3') which is specific for the UCYN lineage (Mazard et al., 2004), and subsequently stained in green with FITC (Fluorescein IsoThioCyanate, TSA-Kit Perkin Elmer, France). DNA from all prokaryotic and eukaryotic cells were counterstained with the specific blue DAPI dye (Sigma-Aldrich, France).

Photomicrographs and cells counts were done according to Biegala and Raimbault (2008). Briefly, entire surfaces of each filter portion (approx. 40 microscopic fields, $0.5 \mathrm{~cm}^{2}$ ) were counted. These surface corresponded in mean to 250 , 100 and $16 \mathrm{~mL}$ of water for the $>10$, the $3-10$ and the $0.2-$ $3 \mu \mathrm{m}$ size fractions, respectively. This filtration protocol allows to detect either UCYN concentration as low as 0.08 to 0.004 cell ml ${ }^{-1}$ depending on size fractions, or filamentous cyanobacteria concentration $>0.004$ cell ml$^{-1}$. The homogeneity of Nitro821-hybridized cells on filters was confirmed by the low standard deviation obtained on triplicate counts done for station $\mathrm{A}, \mathrm{B}$, and $\mathrm{C}$ in the picoplanktonic size fraction $\left(4.6 \pm 0.6,2.3 \pm 0.4\right.$ and $2.3 \pm 0.6$ cell ml $^{-1}$ 
respectively). This homogeneity allowed us to define that the count of an entire filter portion was representative of the whole population for each sample station, and, only one replicate of entire filter portion was counted for each sample. Sizes of Nitro821-targeted cells were determined with the help of $1 \mu \mathrm{m}$ calibration beads (Apogee Flow Systems, UK) according to Le Moal and Biegala (2009).

\subsection{Flow cytometry}

Before PCR assays, PFA fixed C. watsonii (0.5$800 \mathrm{cell} \mathrm{ml}^{-1}$ ) were counted and isolated with the help of a MoFlo cell sorter (Beckman Coulter, Florida, USA) using a $488 \mathrm{~nm}$ laser for phycoerythrin and chlorophyll excitations and $580 \pm 15 \mathrm{~nm}$ band pass and a $640 \mathrm{~nm}$ long pass filters for orange and red emission wavelengths of these pigments. Prior to flow cytometry analysis, cells were centrifuged to remove culture medium and subsequently diluted in MilliQ sterile water to provide a range of concentrations for the test of PCR detection limit. After flow cytometry, cells were collected directly in PCR tubes, in $27 \mu \mathrm{l}$, and stored at $-80^{\circ} \mathrm{C}$ until the addition of PCR mixture. The detection limit of 1 cell ml$l^{-1}$ of $C$. watsonii corresponds to 12 cells per PCR reaction, according to UCYN counts realised on $0.2 \mu \mathrm{m}$ pore-size filter portions from natural samples after TSA-FISH experiments.

\subsection{PCR and cloning}

DNA template used for PCR was not acquired through extraction but directly from entire fixed cells collected for TSAFISH assays on $0.2-3 \mu \mathrm{m}$ size fraction filters. The reason for this modification was the sparse concentration of environmental UCYN (2.3-4.6 cell ml $\left.{ }^{-1}\right)$, which was two to three times lower than the detection limit of $7 \mathrm{cell} \mathrm{ml}^{-1}$ defined for techniques using DNA extraction (Mazard et al., 2004). Filter portions were incubated five times on polysulfone filter support (Millipore, France) in $200 \mu$ of MilliQ sterile water for $5 \mathrm{~min}$ at room temperature. Between incubations water was discarded using a vacuum pump $(200 \mathrm{~mm} \mathrm{Hg})$. The aim of these washing steps was to clean the fixed cells from a white film made of PFA, ethanol and sea salt. For long term stored samples (P5 and M4) dedicated to test the stability of PCR efficiency with time, extracted DNA was also used as PCR template, by filtering $4 \mathrm{~L}$ of waters on $0.2 \mu \mathrm{m}$ pore size Supor filter (Pall, France) under 200-mmHg vacuum and subsequently following the DNA extraction protocol defined in Zehr and Turner (2001).

Diazotroph species richness was investigated by targeting both 16S rDNA and nifH genes. The 16S UCYN specific primer Nitro821 (Eurogentec, France, Table 1) was used in combination with Cya359 (Eurogentec, France, Table 1), according to the original protocol from Mazard et al. (2004), with a slight modification: $0.1 \mathrm{U}$ of Taq polymerase (Promega, France) was used in PCR mixtures instead of 0.650 U. For nifH amplification, nested PCR was used with N3/N4 primers (Table 1) followed by N1/N2 primers (Eurofins MWG, Germany, Table 1), according to Zehr and Turner (2001). All PCR reactions were carried out in $50 \mu \mathrm{l}$ volumes. The first PCR used fixed cells on filters as DNA template and the second PCR used $1 \mu$ of DNA product from the first PCR. A filter with no cell was used as negative control for each environmental sample, to check the absence of contamination among samples, while all labware used to manipulate filters and PCR tubes were previously treated with a combination of bleach, UV radiation, and DNAse away (Molecular BioProducts, Mexico).

PCR products $(10 \mu \mathrm{l}$ or $25 \mu \mathrm{l}$ of $50 \mu \mathrm{l})$ were resolved by gel electrophoresis (Mupidex, France) on a $1.5 \%$ gel agarose (Sigma, France) on $135 \mathrm{~V}$. DNA was stained by ethidium bromide (Euromedex, France, one drop per agarose gel) and amplicons of approximately 460 and $360 \mathrm{bp}$ for $16 \mathrm{~S}$ rDNA and nifH genes respectively, were visualized by a UV-transilluminator (Geldoc UVITEC, France). Amplicons were excised and purified using Wizard ${ }^{\circledR}$ SV Gel and PCR Clean-up system (Promega, France). They were then cloned into a pGEM-T vector (Promega, France), and transformed within strain DH5 $\alpha$ (Invitrogen, France) according to the manufacturer's instructions. Plasmid DNA from ten to twelve positive colonies was purified (Wizard Plus SV Minipreps DNA Purification system, Promega, France) and sequenced using ABI3730XL capillary systems (ABI, Macrogen, Korea). Sequences were deposited in EMBL under accession numbers HQ630785-HQ630811, HQ630813HQ630820.

\subsection{Phylogenetic analyses}

Phylogenetic analyses were performed using the ARB program package (Ludwig et al., 2004). 16S rDNA and nifH databases were download from SILVA (http://www.arb-silva. de/, last access: June 2010) and Marine Microbiology Laboratory from the University of California (J. P. Zehr laboratory, http://pmc.ucsc.edu/ wwwzehr/research/database/, last access: June 2010) websites, respectively. 16S and nifH phylogenetic trees were constructed by the neighbour-joining method with Jukes-Cantor correction. 16S rDNA sequences longer than 1200 base pair (bp) or all nucleotide positions (approx. $360 \mathrm{bp}$ ) between $\mathrm{N} 1$ and $\mathrm{N} 2$ primers (including those obtained in this study) were used. Analyses were bootstrapped 1000 times to evaluate the robustness of tree branches. 16S rDNA partial sequences from this study (approx. $460 \mathrm{bp}$ ) were added to the tree by using the maximumparsimony option from ARB. 
Table 1. 16S rDNA and nifH primers used in this study.

\begin{tabular}{llll}
\hline Primer & Target & Sequence (5' to 3') & Reference \\
\hline Nitro821 & 16S rDNA of UCYN & CAA GCC ACA CCT AGT TTC & Mazard et al. (2004) \\
Cya359 & 16S rDNA of cyanobacteria & GGG GAA TYT TCC GCA ATG GG & Nübel et al. (1997) \\
N1 & nifH of prokaryotes & TGY GAY CCN AAR GCN GA & Zehr and McReynolds (1989) \\
N2 & nifH of prokaryotes & ADN GCC ATC ATY TCN CC & Zehr and McReynolds (1989) \\
N3 & nifH of prokaryotes & ATR TTR TTN GCN GCR TA & Zani et al. (2000) \\
N4 & nifH of prokaryotes & TTY TAY GGN AAR GGN GG & Zani et al. (2000) \\
\hline
\end{tabular}

M: A/C; N: A/T/G/C; R: A/G; Y: C/T; D: A/T/G.

\section{Results}

\subsection{Tests of PCR amplification for the detection of scarce microorganisms}

The detection limit of PCR amplification was successfully decreased from 7 to 1 cell $\mathrm{ml}^{-1}$ by using entire fixed UCYN cell (Crocosphaera watsonii) instead of extracted DNA. 1 cell ml ${ }^{-1}$ corresponds to 12 Crocosphaera cells per PCR reaction (Fig. 2a), and to the lowest number of 12 UCYN per filter portion detected by TSA-FISH technique in this study.

DNA amplification from entire fixed cells was achieved with success on samples stored at $-80^{\circ} \mathrm{C}$ for up to three years and originated from different marine waters (Fig. $2 b_{1}$ and $b_{2}$ ). However, beyond two or three years of storage, environmental DNA could not be amplified and filters must undergo additional washing steps before their introduction into PCR tubes to clean the fixed cells from a white film made of PFA, ethanol and sea salt (Fig. 2b $b_{2}$ ).

\subsection{Diazotrophic cyanobacteria distribution}

Low concentrations of putative diazotrophic cyanobacteria were detected in Mediterranean surface waters using the TSA-FISH technique (Fig. 3). The community was dominated at $99.9 \%$ by picoplanktonic cells hybridized with the UCYN specific probe Nitro821 (Fig. 3a, b, d, e; Fig. 4ad). Two Nitro821-hybridized cell types were detected, small ones from $0.8-1.5 \mu \mathrm{m}$ (Fig. 4a) and large ones from 2.5$3.2 \mu \mathrm{m}$ (Fig. 4b, c). Small cells dominated at 92\% the Nitro821-targeted cells community (Fig. 3). Among these small cells, $75 \%$ were free living-organisms recovered in the $0.2-3 \mu \mathrm{m}$ size fraction (Fig. 3a, d), while $25 \%$ were associated with nonthecate dinoflagellates in the 3-10 and $>10 \mu \mathrm{m}$ size fractions (Fig. 3a, d; Fig. 4d). Dinoflagellates were identified with their typical condensed chromosomes when stained with DAPI (data not shown) and associated Nitro821-hybridized cells were essentially concentrated around the dinoflagellate nucleus where their concentration ranged from 1 to 30 cells (Fig. 4d). Large picocyanobacteria represented only $8 \%$ of the Nitro821-targeted cells (Fig. 3b, e), and were recovered merely as free living cells either in

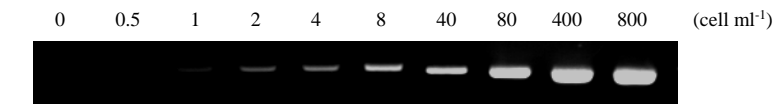

b

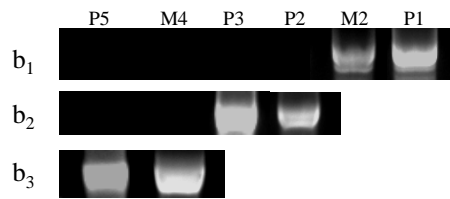

Fig. 2. Different PCR amplification tests for the detection of scarce microorganisms. (a) Definition of PCR detection limit of UCYN using a range of concentrations of $C$. watsonii with Nitro821/Cya359 $16 \mathrm{~S}$ primers. (b) Test of stability of PCR efficiency with time on different types of DNA template collected in the Pacific Ocean $(\mathrm{P})$ or in the Mediterranean Sea (M) and stored at $-80^{\circ} \mathrm{C}$ for 1 to $5 \mathrm{yr}$. Amplifications were done with the general 16S primers 27F/1518R using as DNA template $\left(\mathbf{b}_{1}\right)$ PFA fixed cells collected on filter, $\left(\mathbf{b}_{2}\right)$ PFA fixed cells collected on filter and washed with MilliQ sterile water before amplification, and $\left(\mathbf{b}_{3}\right)$ extracted DNA.

the $0.2-3 \mu \mathrm{m}$ size fraction (Fig. $4 \mathrm{~b}$ ) or in the one of $3-10 \mu \mathrm{m}$ (Fig. 4c). Nitro821-targeted cells were 5.5 times less abundant at $\mathrm{DCM}^{+}$depth than at $12.5 \mathrm{~m}$ (Fig. 3b, c). Their cumulated concentrations ranged from $1-6$ cell ml ${ }^{-1}$ with an average of 3.5 cell ml${ }^{-1}$.

Among filamentous cyanobacteria, only 0.02 filament $\mathrm{ml}^{-1}$ of Richelia intracellularis were detected in the eastern basin at 3 stations (Fig. 3c, f, Fig. 4e), while Trichodesmium spp. was absent or under detection $\left(<0.004\right.$ filament $\left.\mathrm{ml}^{-1}\right)$ all through the transect.

\subsection{Diazotrophs species richness}

UCYN specific 16S rDNA amplification was obtained only from station $\mathrm{A}$ and all the sequences were affiliated to UCYN-A (Fig. 5, Table 2). The presence of UCYN-A was confirmed in station A by nifH phylogenetic analyses, where they accounted for $43 \%$ of the sequences (group $1^{\prime}$, Figs. 6 , 7). In addition to UCYN-A, four diazotroph groups of proteobacteria were recovered by nifH phylogenetic analyses. 

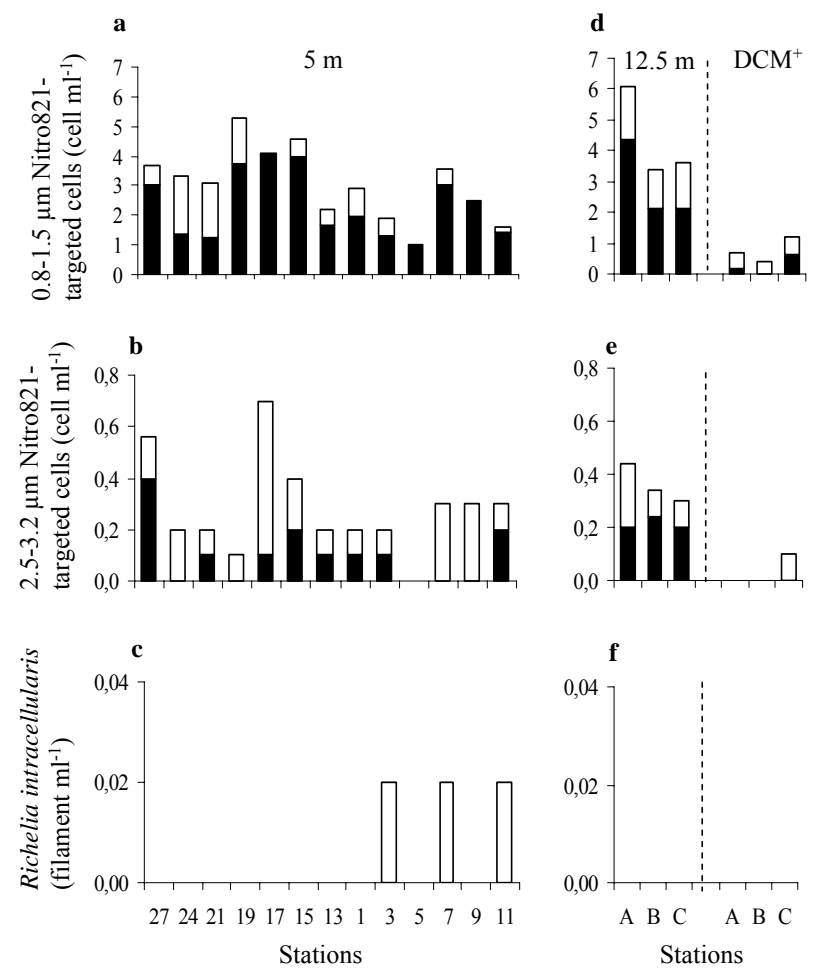

Fig. 3. Epifluorescent microscopic counts of Nitro821-targeted UCYN and filamentous diazotrophic cyanobacteria across the Mediterranean Sea within the 0.2-3 $\mu$ m (black bars) and the 3$10 \mu \mathrm{m}$ combined with $>10 \mu \mathrm{m}$ (white bars) size fractions. Counts were done at $5 \mathrm{~m}$ depth $(\mathbf{a}, \mathbf{b}, \mathbf{c})$ and at two nutrient contrasted depths (d, e, f) including $12.5 \mathrm{~m}$ (left of dotted line) and upper deep chlorophyll maximum $\left(\mathrm{DCM}^{+}\right.$, right of dotted line). Counts were done on small Nitro821-targeted cells (a, d), on large Nitro821targeted cells (b, e), and on Richelia intracellularis (c, f).

Bradyrhizobium sequences dominated nifH clone libraries from station A, B, and C, where they represented $57 \%, 56 \%$, and $75 \%$ of the sequences, respectively (Figs. 6, 7, Table 2). Among them, the new marine group $2^{\prime}$ of Bradyrhizobium was recovered at the three stations, while the group $3^{\prime}$ was detected only at station A. Others rhizobia sequences from group $4^{\prime}$ were detected at station $\mathrm{C}$, when $\gamma$-proteobacteria from group $5^{\prime}$ was detected at station $\mathrm{B}$, accounting for $25 \%$ and $44 \%$ of the nifH clones libraries, respectively (Figs. 6, 7, Table 2).

\section{Discussion}

\subsection{Distribution of diazotrophic cyanobacteria along a Mediterranean transect}

Diazotrophic cyanobacteria have long been considered as the main contributors of $\mathrm{N}_{2}$-fixation in the marine plankton, since they can provide through photosynthesis an autonomous source of organic carbon necessary for this en-

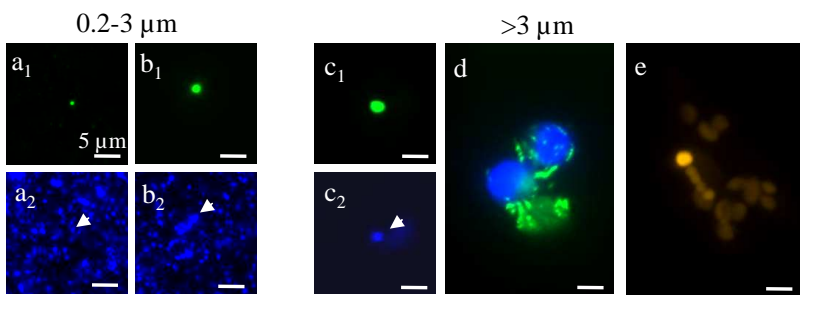

Fig. 4. Epifluorescent photomicrographs from Nitro821-targeted UCYN and filamentous diazotrophic cyanobacteria detected in the Mediterranean Sea. Nitro821-targeted UCYN were labelled with FITC (green fluorescence, $\mathbf{a}_{1}, \mathbf{b}_{1}, \mathbf{c}_{1}$, d) using TSA-FISH technique. $\left(\mathbf{a}_{2}\right),\left(\mathbf{b}_{2}\right),\left(\mathbf{c}_{2}\right)$ and $(\mathbf{d})$ showed corresponding microphotograph of DAPI-stained DNA (blue fluorescence) from all prokaryotic and eukaryotic cells. Arrow heads point to the DNA from the Nitro821-targeted ones. The heterocycstous Richelia intracellularis was detected owning to it natural orange fluorescence (e). Scale bar $=5 \mu \mathrm{m}$.

ergetically expensive process (Stewart, 1971). This first Mediterranean basin-wide study revealed a very low concentration of diazotrophic cyanobacteria, which were dominated at $99.9 \%$ by picoplankton. While Nitro821-targeted UCYN were detected at all stations with a mean concentration of $3.5 \mathrm{cell} \mathrm{ml}^{-1}$, filaments of Trichodesmium $\mathrm{sp}$. were under detection limit $\left(<0.004\right.$ filament $\left.\mathrm{ml}^{-1}\right)$ all through the transect and only 0.02 filament $\mathrm{ml}^{-1}$ of Richelia intracellularis were recovered in the eastern basin. The scarce distribution of these filamentous cyanobacteria was confirmed by plankton net haul data from the same transect (Crombet et al., 2011) as well as by past and recent studies (Trégouboff, 1957; Bar-Zeev et al., 2008). Although Trichodesmium is known to form massive blooms $\left(10^{3}\right.$ filament $\left.\mathrm{ml}^{-1}\right)$ detectable from space in other seas and oceans (Capone et al., 1998; Dupouy et al., 2000), such phenomena have never been observed in the Mediterranean Sea (C. Dupouy, personal communication, 2007). Similarly as for filamentous cyanobacteria, the concentration of UCYN was low in this study and in the same range as the ones previously quantified all through the year in coastal north Mediterranean waters $\left(4.6 \mathrm{cell} \mathrm{ml}^{-1}\right.$ in mean, Le Moal and Biegala, 2009). However, sporadic blooms of UCYN have been reported to reach $10^{2}$ to $10^{3}$ cell ml ${ }^{-1}$ in the same coastal Mediterranean environment, or in Pacific and Atlantic Oceans (reviewed in Table 1 in Le Moal and Biegala, 2009; Moisander et al., 2010).

Among Nitro821-targeted picocyanobacteria, two cell types were detected in this study, small and large ones (0.8 $1.5 \mu \mathrm{m} ; 2.5-3.2 \mu \mathrm{m})$. While the small cell type has been recently discovered in the Pacific Ocean (Biegala and Raimbault, 2008) and confirmed to belong to UCYN-A (Goeble et al., 2008), UCYN-B and C are known to be either picoplanctonic or nanoplantonic cells $(2-10 \mu \mathrm{m}$, Zehr et al., 2001; Ohki et al., 2008). This latter morphological information suggests that the larger Nitro821-targeted cells may 
Table 2. Phylogenetic affiliation of the $16 \mathrm{~S}$ rDNA and nifH sequences.

\begin{tabular}{|c|c|c|c|c|c|}
\hline Gene & $\begin{array}{l}\text { Phylogenetic } \\
\text { groups }\end{array}$ & $\begin{array}{l}\text { No. of } \\
\text { clones }\end{array}$ & $\begin{array}{l}\text { A representative } \\
\text { clone }\end{array}$ & $\begin{array}{l}\text { Closest relative } \\
\text { (accession number)* }^{*}\end{array}$ & $\begin{array}{l}\text { Identity } \\
(\%)\end{array}$ \\
\hline \multirow[t]{2}{*}{$16 \mathrm{~S}$ rDNA } & Group 1 & 9 & BOUM_A1 & Cyanobacterium UCYN-A (CP001842) & 98 \\
\hline & & & & Cyanothece sp. WH 8902 (EU249123) & 96 \\
\hline \multirow{10}{*}{ nifH } & Group $1^{\prime}$ & 3 & BOUM_A4 & Uncultured marine bacterium clone HT70A1_T7 (DQ118201) & 100 \\
\hline & & & & Endosymbiont of Rhopalodia gibba (AY728387) & 85 \\
\hline & Group $2^{\prime}$ & 15 & BOUM_C1 & Uncultured soil bacterium clone DN18 (DQ987562) & 95 \\
\hline & & & & Bradyrhizobium sp. strain ORS391 (FJ347449) & 94 \\
\hline & Group $3^{\prime}$ & 3 & BOUM_A1 & Uncultured bacterium clone GYMC-52B (AJ716286) & 96 \\
\hline & & & & Bradyrhizobium sp. TSA27s (AB542352) & 95 \\
\hline & Group $4^{\prime}$ & 3 & BOUM_C2 & Uncultured bacterium clone NTC9 (GU196843) & 99 \\
\hline & & & & Rhizobium sp. W3 (GQ241353) & 95 \\
\hline & Group $5^{\prime}$ & 4 & BOUM_B2 & Uncultured microorganism clone H05_DNA_E10 (EF568515) & 98 \\
\hline & & & & Denitrovibrio acetiphilus DSM 12809 (CP001968) & 77 \\
\hline
\end{tabular}

* Non-italic represents non-cultivated species; italic represent cultivated species.

be affiliated to UCYN-B or C. However, flow cytometric Mediterranean studies have never reported nanoplanktonic cyanobacteria and the only UCYN detected by phylogenetic analysis belonged to group A (Man Aharanovich et al., 2007).

\subsection{UCYN species richness recovery}

The affiliation of small Nitro821-targeted cells to UCYN-A was confirmed in the western Mediterranean Sea (station A) with both $16 \mathrm{~S}$ and nifH phylogenies (Figs. 5 and 6). It is the first time that UCYN-A are detected at the DNA level in the Mediterranean Sea, thanks to the use of a new PCR protocol dedicated to scarce microorganisms. Entire paraformaldehyde fixed cells collected on a filter serves as PCR DNA template instead of extracted DNA. This allows lessening the detection limit defined by Mazard et al. (2004) from 7 cell ml ${ }^{-1}$ to 1 cell $\mathrm{ml}^{-1}$ in cultures. In a previous Mediterranean study, UCYN-A were recovered off Israeli coast, but only at the transcript level (Man-Aharonovich et al., 2007), likely because these picocyanobacteria were in too low concentration to be recovered after DNA extraction steps. Similar lacks of amplification using extracted DNA have been reported for UCYN-A and other diazotrophs in both marine and freshwater environments (Zani et al., 2000; Hewson et al., 2007). The use of entire cell as DNA PCR template has been previously proposed to reduce the volumes of filtered marine samples down to $25 \mu \mathrm{l}$ including $10^{4}$ bacteria per PCR reaction (Kirchman et al., 2001). These approaches also avoid DNA extractions which are time consuming and generate occasional PCR inhibitors. Although preservatives such as formalin and PFA have been tested on PCR DNA template in past studies, this step was not recommended because it inhibits amplification and generates PCR artefacts (Degiorgi et al., 1994; Kirchman et al., 2001). In this study we were successful with PCR amplification using preservative procedure before PCR assays, similar as the one for TSA-FISH assay, as long as samples were collected within the last four years. Beyond this age inhibitions are shown to increase with time (Fig. 2b). The chemical mixture composed of PFA, ethanol and sea salt is suspected to inhibit subsequent PCR reactions by modifying the salt concentration, and thus the stringence conditions, during the hybridization step between primers and cellular DNA template. Consequently for long term stored samples extracted DNA has to be used as PCR template (Fig. 2 $b_{3}$ ) and direct use of fixed cells as PCR DNA template proved to be a quick and simple protocol to assess the diversity of scarce populations.

Although the PCR protocol dedicated to scarce microorganisms was applied on samples from station $\mathrm{B}$ and $\mathrm{C}$, no UCYN were recovered either by nifH or $16 \mathrm{~S}$ UCYN specific phylogenies. We suspect the cell concentrations to be close to, or below the PCR detection limit. Small and large Nitro821-targeted cells from station B and C were 2 to 20 times less concentrated than small cells identified as UCYNA at station A. Thus, except UCYN-A at station A, diazotrophic cyanobacteria were under detection limit at station $\mathrm{A}, \mathrm{B}$, and $\mathrm{C}$, suggesting that the weak $\mathrm{N}_{2}$ fixation rates measured in the surface layer of the water column (Bonnet et al., 2011; Ridame et al., 2011) can be attributed to other organisms than cyanobacteria.

\subsection{Non-cyanobacterial diazotrophs richness recovery}

In order to search for these organisms, nifH phylogenetic analyses were done. The dominant nifH sequences from the picoplanktonic size fraction of all three clone libraries were Bradyrhizobium, affiliated to $\alpha$-proteobacteria that has so far never been detected in the marine environment (group $2^{\prime}$, Figs. 6, 7). In addition to Bradyrhizobium, two other 

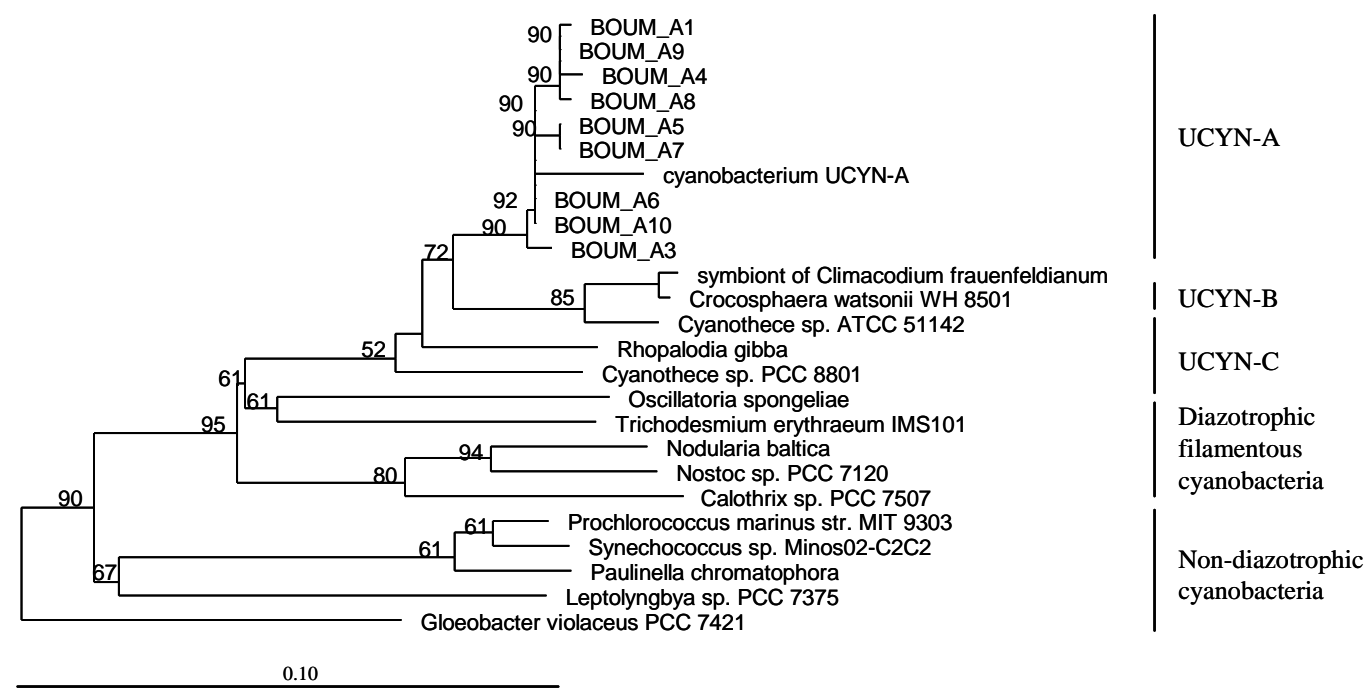

Fig. 5. Phylogenetic tree of $16 \mathrm{~S}$ rDNA sequences from Cyanobacteria. Sequences obtained in this study are referred to (i) by the oceanographic transect BOUM, (ii) the station at which they were sampled (A, B, or C), and (iii) their clone number. Bootstrap values $>50 \%$ are indicated at the nodes. Scale bar $=0.1$ substitution per nucleotides.

groups of rhizobia were identified at stations A and $\mathrm{C}$ (group $3^{\prime}$ and $4^{\prime}$, Fig. 6), while $\gamma$-proteobacteria sequences (group $5^{\prime}$, Fig. 6) were recovered from station B. UCYN-A, $\gamma$ proteobacteria and distantly related $\alpha$-proteobacteria have all been shown to express their nifH gene in the Mediterranean Sea and Pacific or Atlantic Oceans (Falcón et al., 2004; Man Aharanovich et al., 2007; Zehr et al., 2007). Consequently, $\mathrm{N}_{2}$-fixation from the picoplanktonic size fraction (0.05-0.1 nmol N L ${ }^{-1} \mathrm{~d}^{-1}$; Bonnet et al., 2011) could be attributed to a mix of rhizobia in station $\mathrm{C}$, when UCYN-A and $\gamma$-proteobacteria were likely additional contributors to this activity in station $\mathrm{A}$ and $\mathrm{B}$, respectively.

Conversely to free living diazotrophic cyanobacteria, availability of organic carbon may limit non-cyanobacterial planktonic diazotrophs to acquire sufficient energy for nitrogen fixation (Paerl et al., 1987). This explains why in terrestrial and freshwater environments many symbioses have been developed between diazotrophic bacteria and higher plants (Masson-Boivin et al., 2009). These diazotrophic symbionts all cluster within the polyphyletic group of rhizobia, which includes $\alpha$ and $\beta$-proteobacteria. Thanks to these associations, rhizobia are considered as the most efficient heterotrophic $\mathrm{N}_{2}$-fixers as they receive carbon fixed by their photosynthetic host (Evans and Barber, 1977; Van Rhijn and Vanderleyden, 1995). In the marine environment it is well known that diazotrophic bacteria have developed symbiotic relationships with seagrass (Capone, 1983). Diazotrophic bacteria associated with Posidonia oceanica, a seagrass spread all around the Mediterranean Sea, have been estimated to contribute to two-thirds of total nitrogen fixation (Béthoux and Copin-Montégut, 1986). Consequently, it is tempting to speculate that the three groups of rhizo- bia that have been discovered in this study are free living stages of seagrass symbionts. An additional interesting discovery from this study concerns the widely distributed group 2' of Bradyrhizobium, whose closest relatives is the freshwater strain ORS391 (Fig. 6, Table 2). ORS391 belongs to the same Bradyrhizobium species than ORS278 and ORS285 strains that, together with Azorhizobium caulinodans, are the only rhizobia known to be able to fix nitrogen extra-plantae (Dreyfus et al., 1988; N. Nouwen, personnal communication, 2010). This metabolic activity is probably related to their photosynthetic capacity, a common feature among Bradyrhizobium cluster (Giraud and Fleischman, 2004). Despite being diazotrophic, phototrophic free-living bacteria have never been discovered to date in the marine environment (Madigan, 1995; Riemman et al., 2010). We hypothesize though that similar to their closest relatives, the Mediterranean Bradyrhizobium detected in this study are able to acquire an independent source of energy through photosynthesis. Such metabolic capacity may help them to sustain planktonic nitrogen fixation.

\subsection{Factors controlling the distribution of diazotrophic cyanobacteria}

The reasoning developed above proposes hypotheses for the presence of diverse rhizobia community all through the Mediterranean Sea. However it is puzzling that so little diversity (species richness and abundance) of diazotrophic cyanobacteria was recovered, when their presence could be expected in such subtropical oligotrophic Mediterranean waters. Among environmental parameters mentioned to limit diazotrophic cyanobacterial development, temperature, iron 


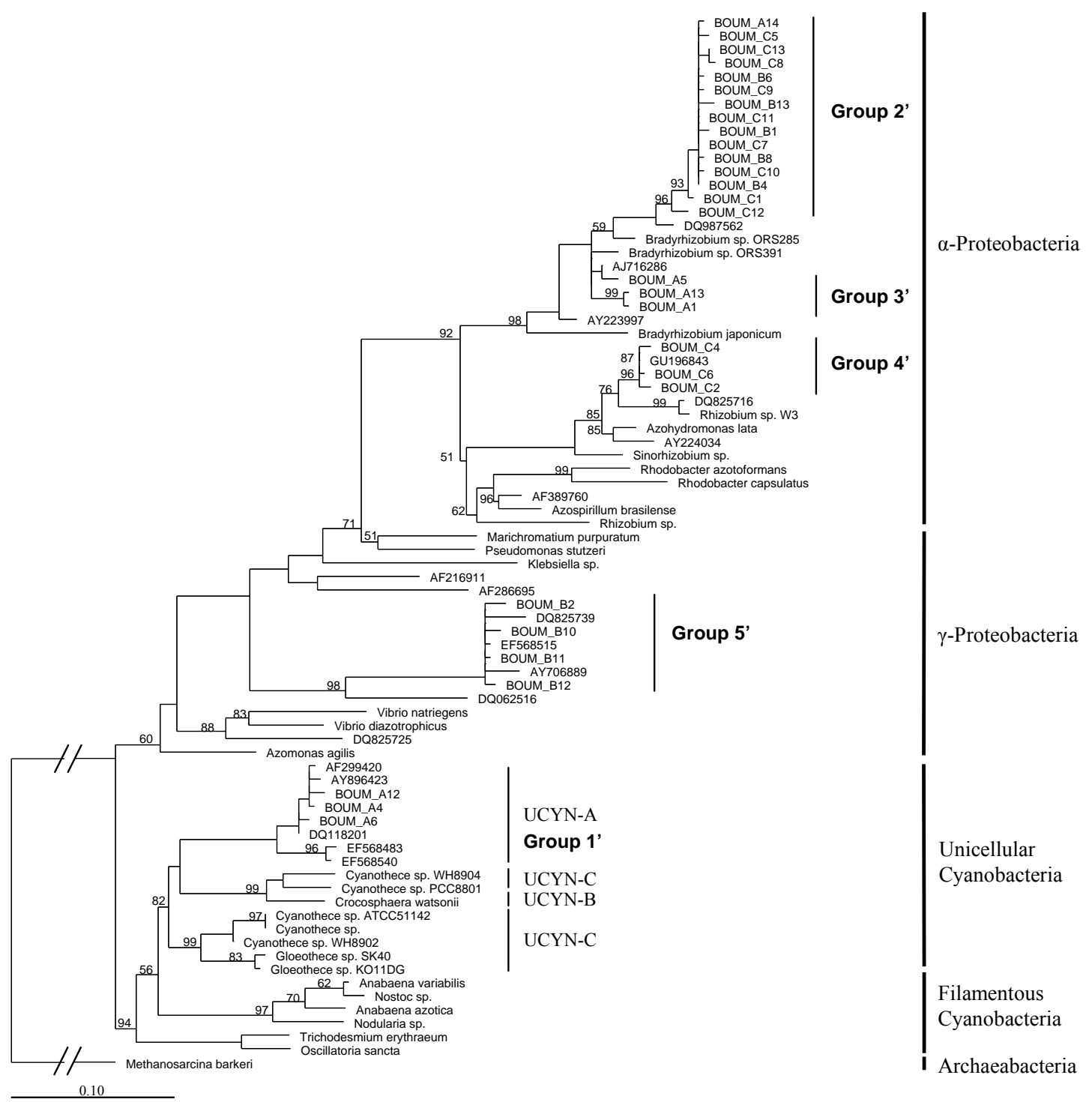

Fig. 6. Phylogenetic tree of nifH sequences. Sequences obtained in this study are referred to (i) by the oceanographic transect BOUM, (ii) the station at which they were sampled (A, B, or C), and (iii) their clone number. Bootstrap values $>50 \%$ are indicated at the nodes. Scale bar $=0.1$ substitution per nucleotides.

and phosphate are the most regularly cited (Mague, 1974; Pearl et al., 1994; Breibarth et al., 2007). High temperature induces stratification of the water column which segregates deep mesotrophic water masses from upper oligotrophic ones. In these warm nutrient deprived waters, diazotrophic cyanobacteria are considered to be at an ecological advantage compared to other phytoplankton species, as they can acquire nitrogen directly from dissolved atmospheric $\mathrm{N}_{2}$ (Tyrell, 1999). Upper mediterranean nitrate-deprived waters were confirmed to be more favorable than deeper and nitrateenriched ones for the development of diazotrophic cyanobacteria, as small Nitro821-targeted UCYN-A were 15 times more abundant at $12.5 \mathrm{~m}$ than at $\mathrm{DCM}^{+}$at station A (Fig. 3d;
Pujo-Pay et al., 2010). Nevertheless, even in these upper waters the diversity of diazotrophic cyanobacteria was low, indicating they were limited by some elements.

Across the Mediterranean Sea, filamentous cyanobacteria were likely inhibited in surface waters by iron and inorganic phosphate, whose concentrations were two orders of magnitude lower than those reported to limit their growth (Mulholland et al., 2002; Berman-Frank et al., 2007; Pujo-Pay et al., 2010; Ternon et al., 2010). Moreover, the phosphate turnover time, which is considered as the first indicator of phosphate availability in oligotrophic marine waters, is 5 times lower in surface Mediterranean waters than the one defined to prevent Trichodesmium spp. growth (Moutin et 
Table 3. Putative phosphorus scavenging genes present in the UCYN-A genome*.

\begin{tabular}{|c|c|c|c|c|c|c|}
\hline Category & $\begin{array}{l}\text { IMG gene } \\
\text { object identifier }\end{array}$ & $\begin{array}{l}\text { Gene } \\
\text { name }\end{array}$ & $\begin{array}{l}\text { Putative } \\
\text { fonction }\end{array}$ & $\begin{array}{l}\% \text { cove- } \\
\text { rage** }\end{array}$ & $\begin{array}{l}\% \text { simila- } \\
\text { rity** }\end{array}$ & Reference \\
\hline Response regulator & 646530709 & phoB & Response regulator & 98 & 66 & Synechococcus sp. WH8102 \\
\hline $\begin{array}{l}\text { High affinity } \\
\text { phosphate transport }\end{array}$ & $\begin{array}{l}646530204 \\
646530201 \\
646530202 \\
646530148 \\
646530199 \\
646530200\end{array}$ & $\begin{array}{l}\text { phoS } \\
\text { pstA } \\
\text { pstC } \\
\text { pstC } \\
\text { pstB } \\
\text { pstB }\end{array}$ & $\begin{array}{l}\text { phosphate binding } \\
\text { phosphate permease } \\
\text { phosphate permease } \\
\text { phosphate permease } \\
\text { ATPase component } \\
\text { ATPase component }\end{array}$ & $\begin{array}{l}98 \\
100 \\
100 \\
97 \\
99 \\
100\end{array}$ & $\begin{array}{l}64 \\
67 \\
70 \\
68 \\
64 \\
66\end{array}$ & $\begin{array}{l}\text { Cyanothece sp. ATCC } 51142 \\
\text { Crocosphaera watsonii WH8501 } \\
\text { Crocosphaera watsonii WH8501 } \\
\text { Synechococcus sp. WH8102 } \\
\text { Synechocystis sp. PCC } 6803 \\
\text { Synechocystis sp. PCC } 6803\end{array}$ \\
\hline $\begin{array}{l}\text { Hydrolysis of } \\
\text { phosphate esters }\end{array}$ & $\begin{array}{l}646530491 \\
646529940 \\
646529952 \\
646530014\end{array}$ & $\begin{array}{l}\text { phoA } \\
- \\
- \\
5 \mathrm{ND}\end{array}$ & $\begin{array}{l}\text { Alkaline phosphatase } \\
\text { Mettalophosphoesterase } \\
\text { Mettalophosphoesterase } \\
\text { 5'-nucleotidase }\end{array}$ & $\begin{array}{l}94 \\
96 \\
97 \\
97\end{array}$ & $\begin{array}{l}57 \\
51 \\
54 \\
61\end{array}$ & $\begin{array}{l}\text { Prochlorococcus marinus CCMP1986 } \\
\text { Trichodesmium erythaeum IMS101 } \\
\text { Cyanothece } \text { sp. PCC } 7424 \\
\text { Synechococcus sp. WH8102 }\end{array}$ \\
\hline $\begin{array}{l}\text { Polyphosphate } \\
\text { metabolism }\end{array}$ & $\begin{array}{l}646530144 \\
646530179\end{array}$ & $\begin{array}{l}\text { ppk } \\
\text { ppa }\end{array}$ & $\begin{array}{l}\text { Polyphosphate kinase } \\
\text { Inorganic pyrophosphatase }\end{array}$ & $\begin{array}{l}96 \\
97\end{array}$ & $\begin{array}{l}53 \\
65\end{array}$ & $\begin{array}{l}\text { Synechococcus sp. WH8102 } \\
\text { Nostoc punctiforme } \mathrm{PCC} 73102\end{array}$ \\
\hline $\begin{array}{l}\text { Phosphonate } \\
\text { transport }\end{array}$ & 646530663 & phnD & ATPase and permease component & 100 & 62 & Synechococcus sp. WH8102 \\
\hline
\end{tabular}

* Publicly available on the Integrated Microbial Genome (IMG, http://img.jgi.doe.gov/cgi-bin/pub/main.cgi).

** Only genes that demonstrated $>50 \%$ identity over $80 \%$ of each protein sequence are presented.

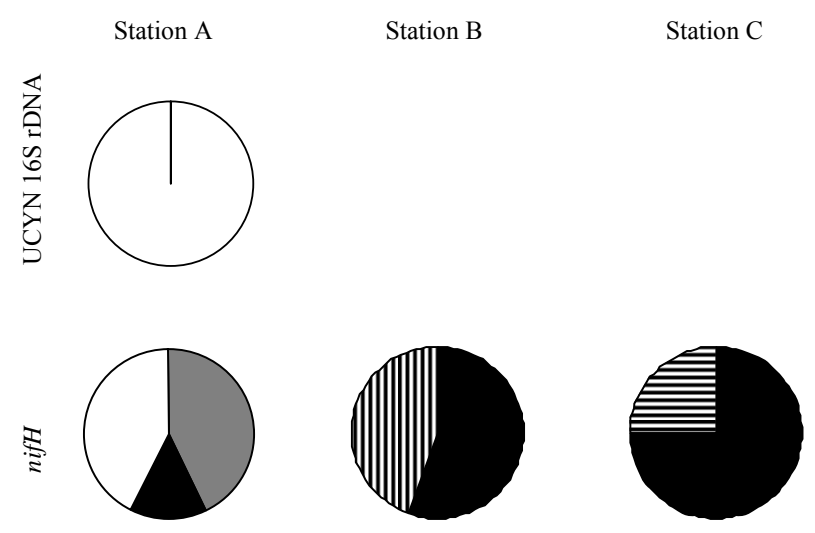

Fig. 7. Percentage of sequences from UCYN specific $16 \mathrm{~S}$ rDNA and nifH clone libraries from station $\mathrm{A}, \mathrm{B}$, and $\mathrm{C}$. Colors indicate phylogenetic groups from Figs. 5 and 6 in which sequences were recovered: UCYN-A group 1' (white); Bradyrhizobium group 2' (black); Bradyrhizobium group 3' (grey); rhizobia group 4' (horizontal lines); $\gamma$-proteobacteria group $5^{\prime}$ (vertical lines).

al., 2005, 2008; Mauriac et al., 2011). Conversely, UCYN have been shown to grow in deprived iron waters and to reach $10^{2}$ to $10^{3}$ cell $\mathrm{ml}^{-1}$ in marine areas using similar or lower inorganic phosphate concentrations (Berman-Frank et al., 2007; see review in Le Moal and Biegala, 2009). The requirements of these different cell types towards phosphate are not reflected by their genomic potential (Dyhrman and Haley, 2006; Orchard et al., 2009). Both Trichodesmium and UCYN-B possess a broad spectrum of genes encoding (i) a high affinity transport system to acquire inorganic phosphate and (ii) for the scavenging of phosphomonoesters, the dominant form of organic phosphate in the marine environment (75\%, Kolowith et al., 2001). In addition, we provide in this study (Table 3) an analysis of the UCYN-A genome with respect to $\mathrm{P}$ which, despite its reduced size, has a similar $\mathrm{P}$ genetic toolbox to that of other picoplanktonic cyanobacteria (Scanlan et al., 2009; Tripp et al., 2010). Interestingly, Trichodesmium seems to be the only marine cyanobacterium that has the potential to scavenge phosphonates, the second major component of organic phosphate $(25 \%$, Kolowith et al., 2001; Dyhrman et al., 2006). Despite this unique genetic equipment Trichodesmium cannot grow efficiently in phosphate deprived waters. Phosphate uptake has been demonstrated to be cell size dependent (Smith and Kalff, 1982; Falcón et al., 2005), hence the low surface/volume ratio of filamentous cyanobacteria seems an obvious disadvantage compare to UCYN to efficiently grow in oligotrophic environment.

While iron and phosphate seem to control the development of Trichodesmium and Richelia, temperature has recently been suspected to limit UCYN (Moisander et al., 2010). At stations where species richness was characterised, temperature was $25^{\circ} \mathrm{C}$ (Moutin et al., 2011), being slightly under or above the optimal temperature range for UCYN-A (23$\left.24^{\circ} \mathrm{C}\right)$ and UCYN-B and C $\left(26-29^{\circ} \mathrm{C}\right.$, reviewed by Le Moal and Biegala, 2009; Moisander et al., 2010). Thus other factors than temperature must co-limit or prevent their development. Still, UCYN-A limiting factors seem slightly relaxed in the less oligotrophic western basin and at coastal station off Israel, where they were recovered (Man-Aharanovich et al., 2007). We suspect carbon to be the controlling factor for UCYN-A development. UCYN-A has been recently 
demonstrated to lack photosystem II, the complex which allows $\mathrm{CO}_{2}$ reduction (Zehr et al., 2008), making it probably dependent on an unknown organic source of carbon, a unique feature among planktonic diazotrophic cyanobacteria. The origin of this carbon puzzles the scientific community, and UCYN-A has been suggested to obtain it from dead particles or other organisms (Tripp et al., 2010). Very interestingly, picoplanktonic Nitro821-targeted cells have been regularly observed, including at station A in this study, in association with dead particles and numerous nonthecate dinoflagellates (Fig. 4d; Biegala and Raimbault, 2008; Bonnet et al., 2009; Le Moal and Biegala, 2009).

\section{Conclusions}

In this first Mediterranean basin wide study, small picoplanktonic cells hybridized with a UCYN specific probe were recovered across the entire Mediterranean Sea, and were confirmed to belong to UCYN-A in the western part of this area. Bradyrhizobium was the most widely distributed diazotroph from the offshore Mediterranean waters, when other diazotrophs were recovered only in one location, such as gamma-proteobacteria in the central Mediterranean Sea, and Richelia intracellularis in addition to rhizobia in the eastern Mediterranean Sea. The photosynthetic diazotrophs Trichodesmium sp., UCYN-B and C were absent or under detection limit, although these free living organisms show a significant degree of nutritional independence towards carbon and nitrogen. While low phosphate and iron concentrations could explain the absence of Trichodesmium sp., limiting factors for the development of UCYN-B and C remain unknown. We hypothesize that the presence of diverse planktonic diazotrophs such as UCYN-A, Richelia intracellularis, rhizobia and gamma-proteobacteria, may be explained by the use of alternative strategies to acquire essential nutrients: (i) similar to their terrestrial counterparts, rhizobia may form punctual symbioses with marine higher plants such as seagrass; (ii) Bradyrhizobium, the most widely distributed diazotroph in this Mediterranean study, could also acquire carbon through photosynthesis; (iii) UCYN-A probably developed associations and/or symbiosis with inert particles or eukaryotes to acquire organic carbon necessary for their development. To answer these hypotheses, further work will be necessary to characterize the different strategies developed by picoplanktonic diazotrophs to acquire carbon in oligotrophic environments.

Acknowledgements. We thank the crew of the R/V Atalante for its help collecting samples. We thank Aude Barrani and the PRECYM (Plate-forme Régionale de Cytométrie pour la Microbiologie) for Crocosphaera cell counts by flow cytometry, and Anne-Flore Deton for PCR amplification tests realised on Pacific filters. We also thank two anonymous reviewers for their helpful comments on this manuscript. This is a contribution of the BOUM (Biogeochemistry from the Oligotrophic to the Ultraoligotrophic Mediterranean) experiment (http://www.com.univ-mrs.fr/BOUM) of the french national LEFE-CYBER program, the European IP SESAME and the inter 25 national IMBER project. This work was supported by a grant from Conseil Régional Provence-Alpes-Côte d'Azur.

Edited by: C. Jeanthon

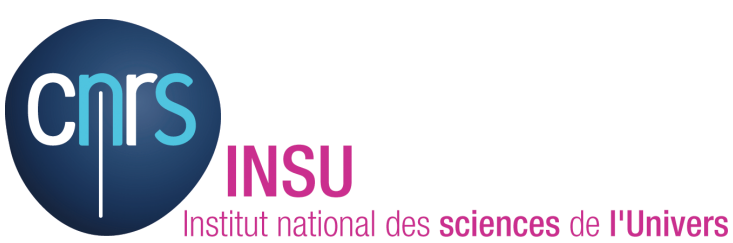

The publication of this article is financed by CNRS-INSU.

\section{References}

Bar Zeev, E., Yogev , T., Man-Aharonovich, D., Kress, N., Herut, B., Beja, O., and Berman-Frank, I.: Seasonal dynamics of the endosymbiotic, nitrogen-fixing cyanobacterium Richelia intracellularis in the eastern Mediterranean Sea, ISME J., 2, 911-923, 2008.

Berman-Frank, I., Quigg, A., Finkel, Z. V., Irwin, A. J., and Haramaty, L.: Nitrogen-fixation strategies and Fe requirements in cyanobacteria, Limnol. Oceanogr., 52, 2260-2269, 2007.

Béthoux, J. P. and Copin-Montégut, G.: Biological fixation of atmospheric nitrogen in the Mediterranean Sea, Limnol. Oceanogr., 31, 1353-1358, 1986.

Biegala, I. C. and Raimbault, P.: High abundance of diazotrophic picocyanobacteria $(<3 \mu \mathrm{m})$ in a Southwest Pacific coral lagoon, Aquat. Microb. Ecol., 51, 45-53, 2008.

Biegala, I. C., Kennaway, G., Alverca, E., Lennon, J.-F., Vaulot, D., and Simon, N.: Identification of bacteria associated with dinoflagellates (Dinophyceae) Alexandrium spp. using tyramide signal amplification-fluorescent in situ hybridization and confocal microscopy, J. Phycol., 38, 404-411, 2002.

Bonnet, S., Biegala, I. C., Dutrieux, P., Slemons, L. O., and Capone, D. G.: Nitrogen fixation in the western equatorial Pacific: rates, diazotrophic cyanobacterial size class distribution, and biogeochemical significance, Global Biogeochem. Cy., 23, GB3012, doi:10.1029/2008GB003439, 2009.

Bonnet, S., Grosso, O., and Moutin, T.: Planktonic dinitrogen fixation in the Mediterranean Sea: a major biogeochemical process during the stratified period?, Biogeosciences Discuss., 8, 11971225, doi:10.5194/bgd-8-1197-2011, 2011.

Breibarth, E., Oschlies, A., and LaRoche, J.: Physiological constraints on the global distribution of Trichodesmium - effect of temperature on diazotrophy, Biogeosciences, 4, 53-61, doi:10.5194/bg-4-53-2007, 2007.

Capone, D. G.: Benthic nitrogen fixation, in: Nitrogen in the marine environment, edited by: Carpenter, E. J., and. Capone, D. G., Academic, 105-137, 1983.

Capone, D. G, Subramaniam, A., Montoya, J. P., Voss, M., Humborg, C., Johansen, A. M., Siefert, R. L., and Carpenter, E. J.: An extensive bloom of the $\mathrm{N}_{2}$-fixing cyanobacterium Trichodesmium erythraeum in the central Arabian Sea, Mar. Ecol. Progr. Ser., 172, 281-292, 1998. 
Chen, Y., Zehr, J. P., and Mellon, M. T.: Growth and nitrogen fixation of the diazotrophic filamentous nonheterocystous cyanobacterium Trichodesmium sp. IMS 101 in defined media: evidence for a circadian rhythm, J. Phycol., 32, 916-923, 1996.

Church, M. J., Jenkins, B. D., Karl, D. M., and Zehr, J. P.: Vertical distributions of nitrogen-fixing phylotypes at Stn ALOHA in the oligotrophic North Pacific Ocean, Aquat. Microb. Ecol., 38, 3$14,2005 \mathrm{a}$

Church, M. J., Short, C. M., Jenkins, B. D., Karl, D. M., and Zehr, J. P.: Temporal patterns of nitrogenase gene (nifH) expression in the oligotrophic North Pacific Ocean, Appl. Environ. Microbiol., 71, 5362-5370, 2005b.

Crombet, Y., Leblanc, K., Quguiner, B., Moutin, T., Rimmelin, P., Ras, J., Claustre, H., Leblond, N., Oriol, L., and Pujo-Pay, M.: Deep silicon maxima in the stratified oligotrophic Mediterranean Sea, Biogeosciences, 8, 459-475, doi:10.5194/bg-8-459-2011, 2011.

De Giorgi, C., Sialer, M. F., and Lamberti, F.: Formalin-induced infidelity in PCR-amplified DNA fragments, Mol. Cell. Probes, 8, 459-462, 1994.

Dupouy, C., Neveux, J., Subramaniam, A., Mulholland, M. R., Montoya, J. P., Campbell, L., Carpenter, E. J., and Capone, D. G.: Satellite captures Trichodesmium blooms in the southwestern tropical Pacific, EOS Trans. Am. Goephys. Union., 81, 13$16,2000$.

Dreyfus, B., Garcia, J. L., and Gillis, M.: Characterization of Azorhizobium caulinodans gen-nov, sp-nov, a stem-nodulating nitrogen-fixing bacterium isolated from Sesbania rostrata, Int. J. Syst. Bacteriol., 38, 89-98, 1988.

Dyhrman, S. T. and Haley, S. T.: Phosphorus scavenging in the unicellular marine diazotroph Crocosphaera watsonii, Appl. Environ. Microbiol., 72, 1452-1458, 2006.

Dyhrman, S. T., Chappell, P. D., Haley, S. T., Moffett, J. W., Orchard, E. D., Waterbury, J. B., and Webb, E. A.: Phosphonate utilization by the globally important marine diazotroph Trichodesmium, Nature, 439, 68-71, 2006.

Evans, H. and Barber, L.: Biological nitrogen fixation for food and fiber production, Science, 197, 332-339, 1977.

Falcón, L. I., Carpenter, E. J., Cipriano, F., Bergman, B., and Capone, D. G.: $\mathrm{N}_{2}$ fixation by unicellular bacterioplankton from the Atlantic and Pacific Oceans: Phylogeny and in situ rates, Appl. Environ. Microbiol., 70, 765-770, 2004.

Falcón, L. I., Sybille Pluvinage, S, and Carpenter, E. J.: Growth kinetics of marine unicellular $\mathrm{N}_{2}$-fixing cyanobacterial isolates in continuous culture in relation to phosphorus and temperature, Mar. Ecol. Prog. Ser., 285, 3-9, 2005.

Falkowski, P. G.: Evolution of the nitrogen cycle and its influence on the biological sequestration of $\mathrm{CO}_{2}$ in the ocean, Nature, 387, 272-275, 1997.

Foster, R. A., Subramaniam, A., Mahaffey, C., Carpenter, E. J., Capone, D. G., and Zehr, J. P.: Influence of the Amazon river plume on distributions of free-living and symbiotic cyanobacteria in the western tropical North Atlantic Ocean, Limnol. Oceanogr., 52, 517-532, 2007.

Giraud, E. and Fleischman, D.: Nitrogen-fixing symbiosis between photosynthetic bacteria and legumes, Photosyn. Res., 82, 115130, 2004.

Goebel, N. L., Edwards, C. A., Carter, B. J., Achilles, K. M., and Zehr, J. P.: Growth and carbon content of three different-sized diazotrophic cyanobacteria observed in the subtropical North Pacific, J. Phycol., 44, 1212-1220, 2008.

Hewson, I., Moisander, P. H., Morrison, A. E, and Zehr, J. P.: Diazotrophic bacterioplankton in a coral reef lagoon: phylogeny, diel nitrogenase expression and response to phosphate enrichment, ISME J., 1, 78-91, 2007.

Ibello, V., Cantoni, C., Cozzi, S., and Civitarese, G.: First basin-wide experimental results on $\mathrm{N}_{2}$ fixation in the open Mediterranean Sea, Geophys. Res. Lett., 37, LO3608, doi:10.1029/2009GL041635, 2010.

Kirchman, D. L., Yu, L., Fuchs, B. M., and Amann, R.: Structure of bacterial communities in aquatic systems as revealed by filter PCR, Aquat. Mircobiol. Ecol., 26, 13-22, 2001.

Kirshtein, J. D., Zehr, J. P., and Paerl, H. W.: Determination of $\mathrm{N}_{2}$ fixation potential in the marine environment: application of the polymerase chain reaction, Mar. Ecol. Prog. Ser., 95, 305-309, 1993.

Kolowith, L. C., Ingall, E. D., and Benner, R.: Composition and cycling of marine organic phosphorus, Limnol. Oceanogr., 46 , 309-320, 2001.

Krom, M. D., Brenner, S., Kress, N., and Gordon, L. I.: Phosphorus limitation of primary productivity in the eastern Mediterranean Sea, Limnol. Oceanogr., 36, 424-432, 1991.

Krom, M. D., Herut, B., and Mantoura, R. F. C.: Nutrient budget for the Eastern Mediterranean: implications for phosphorus limitation, Limnol. Oceanogr., 49, 1582-1592, 2004.

Krom, M. D., Emeis, K.-C., and Van Cappellen, P.: Why is the Eastern Mediterranean phosphorus limited?, Prog. Oceanogr., 85, 236-244, 2010.

Le Moal, M. and Biegala, I. C.: Diazotrophic unicellular cyanobacteria in the Northwestern Mediterranean Sea: a seasonal cycle, Limnol. Oceanogr., 54, 845-855, 2009.

Ludwig, W., Strunk, O., Westram, R., Richter, L., Meier, H., Buchner, A., Lai, T., Steppi, S., Jobb, G., Förster, W., Brettske, I., Gerber, S., Ginhart, A. W., Gross, O., Grumann, S., Hermann, S., Jost, R., König, A., Liss, T., Lüßmann, R., May, M., Nonhoff, B., Reichel, B., Strehlow, R., Stamatakis, A., Stuckmann, N., Vilbig, A., Lenke, M., Ludwig, T., Bode, A., and Schleifer, K.-H.: ARB: a software environment for sequence data, Nucleic Acids Res., 32, 1363-1371, 2004.

Madigan, M. T.: Microbiology of nitrogen fixation by anoxygenic photosynthetic bacteria, in: Anoxygenic photosynthetic bacteria, edited by: Blankenship, E. E., Madigan, M. T., and Bauer, C. E., Kluwer Academic Publisher, The Netherlands, 915-928, 1995.

Mague, T. H., Weare, N. M., and Holm-Hansen, O.: Nitrogen fixation in the North Pacific Ocean, Mar. Biol., 24, 109-119, 1974.

Man-Aharonovich, D., Kress, N., Bar Zeev, E., Berman-Frank, I., and Béjà, O.: Molecular ecology of nifH genes and transcripts in the Eastern Mediterranean Sea, Environ. Microbiol., 9, 2354 2363, 2007.

Masson-Boivin, C., Giraud, E., Perret, X., and Batut, J.: Establishing nitrogen-fixing symbiosis with legumes: how many rhizobium recipes?, Trends Microbiol., 17, 458-466, 2009.

Mauriac, R., Moutin, T., Talarmin, A., and Baklouti, M.: Uncoupling of carbon and phosphate cycles in the photic zone of low-P oligotrophic areas. Part 2: comparison between model simulations and observations during the BOUM cruise, in preparation, 2011.

Mazard, S. L., Fuller, N. J., Orcutt, K. M., Bridle, O., and Scanlan, 
D. J.: PCR analysis of the distribution of unicellular cyanobacterial diazotrophs in the Arabian Sea, Appl. Environ. Microbiol., 70, 7355-7364, 2004.

Moisander, P. H., Beinart, R. A, Hewson, I., White, A. E., Johnson, K. S., Carlson, C. A., Montoya, J. P., and Zehr, J. P.: Unicellular cyanobacterial distributions broaden the oceanic $\mathrm{N}_{2}$ fixation domain, Science, 327, 1515-1518, doi:10.1126/science.1185468, 2010.

Montoya, J. P., Holl, C. M., Zehr, J. P., Hansen, A., Villareal, T. A., and Capone, D. G.: High rates of $\mathrm{N}_{2}$ fixation by unicellular diazotrophs in the oligotrophic Pacific Ocean, Nature, 430, 1027-1031, 2004.

Moutin, T. and Raimbault, P.: Primary production, carbon export and nutrients availability in western and eastern Mediterranean Sea in early summer 1996 (MINOS cruise), J. Mar. Syst., 33-34, 273-288, 2002.

Moutin, T., Van Den Broeck, N., Beker, B., Dupouy, C., Rimmelin, P., and Le Bouteiller, A.: Phosphate availability controls Trichodesmium spp. biomass in the SW Pacific Ocean, Mar. Ecol. Prog. Ser., 297, 15-21, 2005.

Moutin, T., Karl, D. M., Duhamel, S., Rimmelin, P., Raimbault, P., Van Mooy, B. A. S., and Claustre, H.: Phosphate availability and the ultimate control of new nitrogen input by nitrogen fixation in the tropical Pacific Ocean, Biogeosciences, 5, 95-109, doi:10.5194/bg-5-95-2008, 2008.

Moutin, T., Van Wambeke, F., and Prieur, L.: Introduction to the Biogeochemistry from the Oligotrophic to the Ultraoligotrophic Mediterranean (BOUM) experiment, in preparation, 2011.

Mulholland, M. R., Floge, S., Carpenter, E. J., and Capone, D. G.: Alkaline phosphatase activity in relation to phosphorous nutrition in cultures and natural populations of Trichodesmium, Mar. Ecol. Prog. Ser., 239, 45-55, 2002.

Nübel, U., Garcia-Pichel, F., and Muyzer, G.: Primers to amplify 16S rRNA genes from cyanobacteria, Appl. Environ. Microbiol., 63, 3327-3332, 1997.

Ohki, K., Kamiya, M., Honda, D., Kumazawa, S., and Ho, K. K.: Morphological and phylogenetic studies on unicellular diazotrophic cyanobacteria (Cyanophytes) isolated from the coastal waters around Singapore, J. Phycol., 44, 142-151, 2008.

Orchard, E. D., Webb, E. A, and Dyhrman, S. T.: Molecular analysis of the phosphorus starvation response in Trichodesmium spp., Environ. Microbiol., 11, 2400-2411, 2009.

Pearl, H. W., Crocker, K. M., and Prufert L. E.: Limitation of N2 fixation in coastal marine waters: relative importance of molybdenum, iron, phosphorus, and organic matter availability, Limnol. Oceanogr., 32, 525-536, 1987.

Pearl, H. W., Prufert-Berout, L. E., and Guo, C.: Iron stimulated $\mathrm{N}_{2}$ fixation and growth in natural and cultured populations of the planktonic marine cyanobacteria Trichodesmium spp., Appl. Environ. Microbiol., 60, 1044-1047, 1994.

Pujo-Pay, M., Conan, P., Oriol, L., Cornet-Barthaux, V., Falco, C., Ghiglione, J.-F., Goyet, C., Moutin, T., and Prieur, L.: Integrated survey of elemental stoichiometry $(\mathrm{C}, \mathrm{N}, \mathrm{P})$ from the Western to Eastern Mediterranean Sea, Biogeosciences Discuss., 7, 73157358, doi:10.5194/bgd-7-7315-2010, 2010.

Rees, A. P., Law, C. S., and Woodward, E. M. S.: High rates of nitrogen fixation during an in situ phosphate release experiment in the Eastern Mediterranean Sea, Geophys. Res. Lett., 33, L10607, doi:10.1029/2006GL025791, 2006.
Ridame, C., Le Moal, M., Guieu, C., Ternon, E., Biegala, I. C., L'Helguen, S., and Pujo-Pay, M.: Nutrient control of $\mathrm{N}_{2}$ fixation in the oligotrophic Mediterranean Sea and the impact of Saharan dust events, Biogeosciences Discuss., 8, 2629-2657, doi:10.5194/bgd-8-2629-2011, 2011.

Riemann, L., Farnelid, H., Steward, G. F.: Nitrogenase genes in non-cyanobacterial plankton: prevalence, diversity and regulation in marine waters, Aquat. Microb. Ecol., 61, 235-247, doi:10.3354/ame01431, 2010.

Rosado, A. S., Duarte, G. F., Seldin, L., and Dirk Van Elsas, J.: Genetic diversity of nifH gene sequences in Paenibacillus azotofixans strains and soil samples analyzed by denaturing gradient gel electrophoresis of PCR-amplified gene fragments, Appl. Environ. Microbiol., 64, 2770-2779, 1998.

Sandroni, V., Raimbault, P., Migon, C., Garcia, N., and Gouze, E.: Dry atmospheric deposition and diazotrophy as sources of new nitrogen to northwestern Mediterranean oligotrophic surface waters, Deep Sea Res., 54, 1859-1870, 2007.

Sañudo-Wilhelmy, S. A., Kustka, A., Gobler, C. J., Hutchins, D. A., Capone, D. G., Raven, J. A., and DiGiacomo, P. M.: Phosphorus limitation of nitrogen fixation by Trichodesmium in the central Atlantic Ocean, Nature, 411, 66-69, 2001.

Scanlan, D. J., Ostrowski, M., Mazard, S., Dufresne, A., Garczarek, L., Hess, W. R., Post, A. F., Hagemann, M., Paulsen, I., and Partensky, F.: Ecological genomics of marine picocyanobacteria, Microb. Mol. Biol. Rev., 73, 249-299, 2009.

Smith, R. E. H. and Kalff, J.: Size-dependent phosphorus uptake kinetics and cell quota in phytoplankton, J. Phycol., 18, 275$284,1982$.

Stewart, W. D. P.: Nitrogen fixation in the Sea, in: Fertility of the Sea, edited by: Costlow, J. D., Gordon Breach, New York, 2, 537-564, 1971.

Ternon, E., Guieu, C., Ridame, C., L'Helguen, S., and Catala, P.: Longitudinal variability of the biogeochemical role of Mediterranean aerosols in the Mediterranean Sea, Biogeosciences Discuss., 7, 8087-8121, doi:10.5194/bgd-7-8087-2010, 2010.

Trégouboff, G.: Myxophyceae (= Cyanophycées), in: Manuel de planctonologie Méditerranéenne, $2 n$ Edn., edited by: Trégouboff G., and Rose M., Centre National de la Recherche Scientifique, 33-34, 1957.

Tripp, J. H., Bench, S. R., Turk, K. A., Foster, R. A., Desany, B. A., Niazi, F., Affourtit, J. P., and Zehr, J. P.: Metabolic streamlining in an open-ocean nitrogen-fixing cyanobacterium, Nature, 464, 90-94, 2010.

Tyrell, T.: The relative influences of nitrogen and phosphorus on oceanic primary production, Nature, 400, 525-531, 1999.

Van Rhijn, P. and Vanderleyden, J.: The Rhizobium-Plant Symbiosis, Microbiol. Rev., 59, 124-142, 1995.

Zani, S., Mellon, M. T., Collier, J. L., and Zehr, J. P.: Expression of nifH genes in natural microbial assemblages in Lake George, New York, detected by reverse transcriptase PCR, Appl. Environ. Microbiol., 66, 3119-3124, 2000.

Zehr, J. P. and Turner, P. J.: Nitrogen fixation: nitrogenase genes and gene expression, Methods Microbiol., 30, 271-286, 2001.

Zehr, J. P., Waterbury, J. B., Turner, P. J., Montoya, J. P., Omoregie, E., Steward, G. F., Hansen, A., and Karl, D. M.: Unicellular cyanobacteria fix $\mathrm{N}_{2}$ in the subtropical North Pacific Ocean, Nature, 412, 635-638, 2001.

Zehr, J. P., Jenkins, B. D., Short, S. M., and Steward, G. F.: Nitroge- 
nase gene diversity and microbial community structure: a crosssystem comparison, Environ. Microbiol., 7, 539-554, 2003.

Zehr, J. P., Montoya, J. P., Jenkins, B. D., Hewson, I., Mondragon, E., Short, C. M., Church, M. J., Hansen, A., and Karl, D. M.: Experiments linking nitrogenase gene expression to nitrogen fixation in the North Pacific subtropical gyre, Limnol. Oceanogr., 52, 169-183, 2007.
Zehr, J. P., Bench, S., Carter, B. J., Hewson, I., Niazi, F., Shi, T., Tripp, H. J., and Affourtit, J. P.: Globally distributed uncultivated oceanic $\mathrm{N}_{2}$-fixing cyanobacteria lack oxygenic photosystem II, Science, 322, 1110-1112, 2008. 